\title{
Interferon Lambda Delays the Emergence of Influenza Virus Resistance to Oseltamivir
}

\author{
Chiara Medaglia ${ }^{1,+}$, Arnaud Charles-Antoine Zwygart ${ }^{1,+}$, Paulo Jacob Silva ${ }^{2}$, Samuel Constant ${ }^{3}$, Song Huang ${ }^{3}$, \\ Francesco Stellacci ${ }^{2}$ and Caroline Tapparel ${ }^{1, *}$ \\ 1 Department of Microbiology and Molecular Medicine, University of Geneva, 1206 Geneva, Switzerland; \\ chiara.medaglia@unige.ch (C.M.); arnaud.zwygart@unige.ch (A.C.-A.Z.) \\ 2 Insitute of Materials, Ecole polytechnique fédérale de Lausanne, 1015 Lausanne, Switzerland; \\ paulo.jacob@epfl.ch (P.J.S.); francesco.stellacci@epfl.ch (F.S.) \\ 3 Epithelix Sas, 1228 Geneva, Switzerland; samuel.constant@epithelix.com (S.C.); \\ song.huang@epithelix.com (S.H.) \\ * Correspondence: caroline.tapparel@unige.ch \\ + These authors contributed equally to this work.
}

check for

updates

Citation: Medaglia, C.; Zwygart, A.C.-A.; Silva, P.J.; Constant, S.; Huang, S.; Stellacci, F.; Tapparel, C. Interferon Lambda Delays the Emergence of Influenza Virus Resistance to Oseltamivir. Microorganisms 2021, 9, 1196. https://doi.org/10.3390/ microorganisms 9061196

Academic Editor: Mario Clerici

Received: 24 February 2021

Accepted: 28 May 2021

Published: 1 June 2021

Publisher's Note: MDPI stays neutral with regard to jurisdictional claims in published maps and institutional affiliations.

Copyright: (c) 2021 by the authors. Licensee MDPI, Basel, Switzerland. This article is an open access article distributed under the terms and conditions of the Creative Commons Attribution (CC BY) license (https:// creativecommons.org/licenses/by/ $4.0 /)$.

\begin{abstract}
Influenza viruses are a leading cause of morbidity and mortality worldwide. These airborne pathogens are able to cross the species barrier, leading to regular seasonal epidemics and sporadic pandemics. Influenza viruses also possess a high genetic variability, which allows for the acquisition of resistance mutations to antivirals. Combination therapies with two or more drugs targeting different mechanisms of viral replication have been considered an advantageous option to not only enhance the effectiveness of the individual treatments, but also reduce the likelihood of resistance emergence. Using an in vitro infection model, we assessed the barrier to viral resistance of a combination therapy with the neuraminidase inhibitor oseltamivir and human interferon lambda against the pandemic H1N1 A/Netherlands/602/2009 (H1N1pdm09) virus. We serially passaged the virus in a cell line derived from human bronchial epithelial cells in the presence or absence of increasing concentrations of oseltamivir alone or oseltamivir plus interferon lambda. While the treatment with oseltamivir alone quickly induced the emergence of antiviral resistance through a single mutation in the neuraminidase gene, the co-administration of interferon lambda delayed the emergence of drug-resistant influenza virus variants. Our results suggest a possible clinical application of interferon lambda in combination with oseltamivir to treat influenza.
\end{abstract}

Keywords: influenza virus; oseltamivir; interferon lambda; neuraminidase; antiviral resistance

\section{Introduction}

Influenza is an infectious respiratory disease caused in humans by influenza A (IAV) and influenza B (IBV) viruses. It affects approximately 1 billion individuals each year and, according to the World Health Organization, the annual mortality burden of this disease spans between 250,000 and 500,000 deaths worldwide [1]. Besides the annual seasonal epidemics, more rare and unpredictable pandemic outbreaks that involve IAVs of zoonotic origin also represent a threat. IAVs cause pandemics when they acquire the ability to infect and transmit between different species, generating an antigenically novel virus [2]. In the past hundred years, four influenza pandemics occurred, all associated with higher mortality rates than seasonal epidemics [3]. In this time frame, globalization has driven social and economic changes that have enhanced the threat of disease emergence and accelerated the spread of novel strains. Due to their error-prone polymerase, IVs rapidly acquire genetic variability that inevitably culminates in the emergence of resistance to antivirals. Even changes in a very small number of amino acid residues in the targeted viral protein can be sufficient to reduce or completely block the efficacy of a drug [4]. Importantly, antiviral resistance may not necessarily result from the drug selective pressure, but it can also develop in the absence of treatments [5]. 
The neuraminidase inhibitors (NAIs) oseltamivir, peramivir, zanamivir, and laninamivir are currently the first-line treatment for both IAV and IBV. They competitively inhibit neuraminidase (NA) on the surface of newly formed viral particles, thus preventing their shedding from the host cells. One strength of the NAIs over the older adamantanes is that they are less prone to select for resistant mutants [6,7]. Therefore, the emergence of resistant variants against this class of antivirals, about 15 years ago, was a cause of immediate concern $[8,9]$. Oseltamivir (OS), sold under the brand name Tamiflu ${ }^{\mathrm{TM}}$, is taken per os and used for both the treatment and the prophylaxis of influenza. Among the NAIs, OS is certainly the most commonly used because it can easily be self-administered [10]. A single H275Y amino acid substitution (H274Y in N2 numbering) in the IAV NA gene confers resistance to OS [11,12]. This substitution emerged first in the seasonal influenza A H1N1 (A/Brisbane/59/2007-like) strain in 2007 and rapidly spread to all H1N1 strains [13]. The 2009 H1N1pdm09 was fortunately sensitive to the drug although clusters of OS-resistant (OR) strains are detected at low frequency $(<2 \%)[14-18]$, posing a threat of global spread of resistance as occurred with the seasonal pre-pandemic H1N1. In influenza wild-type strains, the NA active site changes shape to accommodate OS. H275Y inhibits the binding of the drug by preventing this conformational change. This mutation reduces the susceptibility of H1N1 IAV to OS by approximately 400-fold [19]. Moreover, due to the acquisition of additional permissive mutations preserving viral fitness, the $\mathrm{H} 275 \mathrm{Y}$ variants have been shown to persist even after cessation of the treatment, with a morbidity and mortality profile similar to their wild-type counterparts [12,20]. Similar resistance problems are encountered when using the other anti-IV antivirals, including the most recent ones, targeting the RNA-dependent RNA polymerase (RdRp) [21]. Thus, there is an unmet need for new treatment regimens that can reduce the risk of resistance appearance.

Combination therapy is considered to be a valuable approach to limit the emergence of drug resistance. The rationale behind this concept is that while IV can rapidly develop resistance to a single antiviral, it takes longer to develop resistance to two or more drugs simultaneously [22]. In line with that, combining drugs targeting different mechanisms of viral replication may be more effective in decreasing the emergence of resistance, as demonstrated when amantadine and ribavirin were combined with OS in an in vivo mouse model of influenza [23]. Given that scenario, we chose to optimize the use of OS and to evaluate its propensity to select for resistant mutants when administered alone or together with human interferon lambda 1 (IFN $\lambda 1$ ).

Interferons (IFNs) are a class of innate cytokines produced in response to viral infection. IFNs type I and type III (alias IFN $\lambda$ ) are the host frontline defense against viruses. Once they bind to their receptors, IFNs activate a gene expression program that induces an antiviral state and limits the spread of the infection [24]. IFN type I is an FDA-approved drug [25]. However, as it is able to directly activate immune effector cells, IFN type I can trigger a massive immune response that may exacerbate the outcome of influenza infection [26]. On the other hand, IFN $\lambda$, thanks to its restricted receptor distribution, only acts on the epithelial barriers, without causing the adverse inflammatory effects associated with IFN type I $[27,28]$. These properties suggest IFN $\lambda$ as a treatment of choice against viral infections, with a higher tolerability than IFN type I. Several studies demonstrate that IFN $\lambda$ enhances the adaptive immune response in the respiratory mucosa, without compromising the host fitness $[29,30]$. IFN $\lambda$ was also found to play a critical early role, not shared by IFN type I, in protection of the lung following influenza virus infection $[31,32]$. It is reported that IFN $\lambda$ exerts variable degrees of antiviral activity in vivo without emergence of resistance against both IV viruses [33]. Moreover, human IFN $\lambda 1$ has been successfully used in clinical trials against hepatitis C [33-37].

Previous studies have proved that OS and IFN $\lambda 1$ display synergistic antiviral activity against the H1N1 IAV [38] but, to the best of our knowledge, their combined effect on the emergence of antiviral resistance has never been addressed. Hence, we asked whether the co-administration of these two classes of anti-influenza drugs could alter the emergence of resistant variants. We used Calu-3 cells, derived from human bronchial submucosal 
glands [39], to serially passage H1N1pdm09 influenza virus in the presence of increasing concentrations of OS, IFN $\lambda 1$, OS plus IFN $\lambda 1$, or medium alone to generate viral variants that displayed various degrees of antiviral resistance. Calu- 3 cells effectively support IV infection and represent a reliable model to evaluate the emergence of NAI resistant strains, as well as the interaction between OS and IFN $\lambda 1$.

\section{Materials and Methods}

\subsection{Cells, Tissues, Viruses, and Compounds}

Madin-Darby canine kidney (MDCK) and Calu-3 cell lines were obtained from the American Type Culture Collection (Manassas, VA, USA). Calu-3 cells were cultured in Minimum Essential Medium (MEM) supplemented with GlutaMAX ${ }^{\mathrm{TM}}, 10 \%$ FBS, Phenol Red, $1 \%$ Hepes, $1 \%$ Non-Essential Amino Acids, $1 \%$ penicillin/streptomycin, and 1\% Sodiumpyruvate and grown at $37{ }^{\circ} \mathrm{C}$ in an atmosphere of $5 \% \mathrm{CO}$. MDCK cells were cultured in Dulbecco's Modified Eagle Medium (DMEM) supplemented with GlutaMAX ${ }^{\mathrm{TM}}$, Sodium Pyruvate, Phenol Red, $10 \%$ FBS, and $1 \% \mathrm{P} / \mathrm{S}$ and grown at $37^{\circ} \mathrm{C}$ in an atmosphere of $5 \%$ $\mathrm{CO} 2$. Human ex vivo reconstituted upper respiratory tissues, Mucilair, were purchased from Epithelix (Geneva, Switzerland) and maintained in an air-liquid interface according to the manufacturer's instructions [40].

Human recombinant IFN $\lambda 1$ protein was obtained from R\&D Systems, Inc. (Abingdon, United Kingdom). OS carboxylate was provided by Roche Diagnostics $\mathrm{GmbH}$ (Mannheim, Germany).

Human H1N1, A/Netherlands/602/2009 influenza virus (A(H1N1)pdm09), kindly provided by Prof. Mirco Schmolke (University of Geneva), was amplified and titrated in MDCK cells by plaque assay. For viral stock production, the cells were infected with a multiplicity of infection (MOI) of $0.01 \mathrm{PFU} /$ cell in serum-free DMEM for $1 \mathrm{~h}$ at $37^{\circ} \mathrm{C}$. The inoculum was then removed and fresh serum-free medium containing $1 \mu \mathrm{g} / \mathrm{mL}$ of TPCK trypsin was added. The infectious supernatant was collected $48 \mathrm{~h}$ post infection (hpi), aliquoted, and frozen at $-80{ }^{\circ} \mathrm{C}$ before titration. Viral stocks of $\mathrm{A}(\mathrm{H} 1 \mathrm{~N} 1) \mathrm{pdm} 09$ variants were prepared in Calu- 3 cells infected with a MOI of $0.1 \mathrm{PFU} /$ cell, in serum-free MEM for $1 \mathrm{~h}$ at $37^{\circ} \mathrm{C}$. Upon inoculum removal, fresh serum-free medium was added and the infectious supernatant was collected at $48 \mathrm{hpi}$, aliquoted, and frozen at $-80^{\circ} \mathrm{C}$ before titration in MDCK cells. All experimental work was performed in a biosafety level 2 laboratory approved for use of these strains.

\subsection{Cell Viability Assay}

Calu-3 cells $\left(1 \times 10^{5}\right.$ cells per well $)$ were seeded in a 96-well plate one day before the assay. A dose range of IFN $\lambda 1$ (spanning from $125 \mathrm{ng} / \mathrm{mL}$ to $1 \mu \mathrm{g} / \mathrm{mL}$ ), OS (spanning from 160 to $640 \mu \mathrm{M}$ ), or IFN $\lambda 1$ plus OS was added to the cells in serum-free MEM for $48 \mathrm{~h}$. MTT reagent (Promega) was added to the cells for $3 \mathrm{~h}$ at $37^{\circ} \mathrm{C}$ according to the manufacturer's instructions. Subsequently, the absorbance was read at $570 \mathrm{~nm}$. Percentages of viability were calculated by comparing the absorbance in treated wells and untreated conditions.

\subsection{Infectivity of A(H1N1)pdm09 Influenza Viruses Measured by Plaque Assay in MDCK}

The infectivity of the WT virus and the selected variants was determined by at least two independent plaque assays. Briefly, confluent cultures of MDCK cells in 6 multiwell plates were incubated at $37^{\circ} \mathrm{C}$ for $1 \mathrm{~h}$ with 10 -fold serial dilutions of each virus prepared in serum-free DMEM containing 1\% penicillin/streptomycin. Upon inoculum removal, the cells were washed and overlaid with MEM containing 0.3\% BSA, 0.9\% Bacto agar, and $1 \mu \mathrm{g} / \mathrm{mL}$ TPCK-treated trypsin. After $48 \mathrm{~h}$ of incubation at $37^{\circ} \mathrm{C}$, the cells were fixed with $4 \%$ formaldehyde solution and then stained with $0.1 \%$ crystal violet. The number of PFUs per dilution was determined using a fine scale magnifying comparator and a white light table. 


\subsection{Virus Yield Reduction Assay in Calu-3 Cells}

Confluent layers of Calu-3 cells seeded in 96-well plates were infected with a MOI of $0.1 \mathrm{PFU} /$ cell of the original viral stock or with the four selected variants (i.e., OS $\mathrm{p} 9, \lambda \mathrm{p} 9$, $\mathrm{OS} / \lambda \mathrm{p} 9$, and UTR p9) in serum-free MEM for $1 \mathrm{~h}$ at $37^{\circ} \mathrm{C}$.

A dose range of IFN $\lambda 1$ spanning from $12.5 \mathrm{ng} / \mathrm{mL}$ to $100 \mathrm{ng} / \mathrm{mL}$ was added to the cells for $24 \mathrm{~h}$ before infection. One hour post infection, the inoculum was removed and the same dose range of drug was added to the cells. A dose range of OS spanning from $1.8 \mu \mathrm{M}$ to $15 \mu \mathrm{M}$ was added only at $1 \mathrm{hpi}$ and the cells were further incubated in a drug-containing medium for $24 \mathrm{~h}$. Then, the supernatant was collected and infectious virus yields were determined as the number of PFUs $/ \mathrm{mL}$ in MDCK cells. The drug concentration that caused a 50\% decrease in the PFU titer in comparison to control wells without drug was defined as the half maximal effective concentration (EC50). The results of two independent experiments, each consisting of two replicates, were averaged. The EC50 values were calculated using Prism 8.0 (GraphPad, San Diego, CA, USA).

\subsection{Selection of Resistant Variants}

A(H1N1)pdm09 influenza viruses were successively passaged with a MOI of $0.1 \mathrm{PFU} /$ cell in Calu-3 cells, seeded in 6-well plates, in the presence or absence of OS, IFN $\lambda$, OS plus IFN $\lambda$, or serum-free MEM only. The first administered dose of each compound, $10 \mu \mathrm{M}$ for OS and $37 \mathrm{ng} / \mathrm{mL}$ for IFN $\lambda$, was doubled at each passage until the toxic dose was reached. Human IFN $\lambda 1$ was administered $24 \mathrm{~h}$ before the infection (hbi) and then the same dose of drug was added to the cells at $1 \mathrm{hpi}$, right after the inoculum removal. OS was always administered $1 \mathrm{hpi}$, in both single and combined treatments. The cells were thus incubated in a drug containing medium for $48 \mathrm{~h}$. Then, the supernatants were collected and centrifuged at $3000 \mathrm{rpm}$ for $5 \mathrm{~min}$ in order to separate the dead cells from the viral suspensions. The supernatants were aliquoted and stored at $-80^{\circ} \mathrm{C}$ before being titrated in MDCK. Infectious virus yields were determined as the number of PFU $/ \mathrm{mL}$ in MDCK cells. The $p$ values were calculated on logarithmic values using the two-way ANOVA with Prism 8.0 (GraphPad, San Diego, CA, USA).

\subsection{Assessment of Viral Fitness in Calu-3 and in Respiratory Tissues}

To determine viral fitness in vitro, Calu-3 cells were infected with the A(H1N1)pdm09 viruses (the original viral stock or the four selected variants) at a MOI of $0.01 \mathrm{PFU} /$ cell. After incubation for $1 \mathrm{~h}$, the cells were washed and overlaid with serum-free MEM containing $1 \%$ penicillin/streptomycin. The infectious supernatants were collected at 24,48 , and $72 \mathrm{hpi}$ and stored at $-80^{\circ} \mathrm{C}$ until titration in MDCK cells. At each time point, the entire supernatant was collected and new medium was added, thus allowing for the measurement of daily viral production.

To determine viral fitness ex vivo, Mucilair tissues were infected on their apical side with $5 \times 10^{4} \mathrm{PFU} /$ tissue of the $\mathrm{A}(\mathrm{H} 1 \mathrm{~N} 1) \mathrm{pdm} 09$ viruses. The viruses were diluted in Mucilair medium and the infection was performed at $33^{\circ} \mathrm{C}$ for $4 \mathrm{~h}$. The inocula were then removed and the tissues were washed 5 times with DPBS [40]. The viral particles released from the apical side of the tissues were recovered every $24 \mathrm{~h}$ for four days and then the number of RNA copies were obtained by RT-qPCR [40].

\subsection{RT-qPCR Analysis and Viral RNA Copies Quantification}

Viral RNA was extracted from Mucilair apical washes using an EZNA viral extraction kit (Omega Biotek, Norcross, GA, USA) and quantified by using RT-qPCR with the QuantiTect kit (\#204443; Qiagen, Hilden, Germany) in a StepOne ABI Thermocycler. Viral RNA copies were quantified as follows: 4 ten-fold dilution series of in vitro transcripts of the influenza A/California/7/2009(H1N1) M gene were used as the reference standard as previously described [41]. CT values were converted into RNA load using the slope-intercept form. In all experiments, the slope, efficiency, and R2 ranged between 0.96 and 0.99 [40,42]. 


\subsection{Virus Sequencing}

Viral RNAs were isolated from virus-containing cell culture fluid after passages in Calu-3 cells. Samples were then reverse-transcribed. The RT reaction was performed with a mix composed of First Strand Buffer $5 \times$ (InvitrogenTM), H2O Rnase free, Superscript ${ }^{\circledR}$ III RT/Platinum ${ }^{\circledR}$ Taq Mix (InvitrogenTM), 0.1 M DTT (InvitrogenTM), dNTPs ( $25 \mathrm{mM})$, Protector RNase inhibitor $(40 \mathrm{U} / \mu \mathrm{L})$ (Roche), and Random hexamers $(50 \mu \mathrm{g} / \mu \mathrm{L})$ (InvitrogenTM).

Viral gene segments were then amplified from the viral cDNA using a master mix composed of $10 \times$ PCR Rxn buffer (-MgCl2) (InvitrogenTM), $50 \mathrm{mM} \mathrm{MgCl} 2$ (InvitrogenTM), H2O Rnase free, Platinum ${ }^{\circledR}$ Taq DNA polymerase $(5 \mathrm{U} / \mu \mathrm{L})$ (InvitrogenTM), dNTPs (10 mM), and M13-tailed primers specific for the hemagglutinin (HA) and NA segments (Table 1). The length and the quality of the amplified fragments were verified by electrophoresis in an agarose gel 1\% with $4 \mu \mathrm{L}$ of Syber-safe and purified with an MSB Spin PCRapace column (Stratec, Berlin, Germany). The samples were sequenced through the Fasteris DNA sequencing service (Geneva) and then analyzed using the Geneious program [43]. For minority species analysis, an internal sequencing primer was used (Table 1, NA seq).

Table 1. Primers used to amplify gene segments of A(H1N1)pdm09 viruses.

\begin{tabular}{|c|c|c|c|}
\hline Gene & Primer & Binding Position & Sequence * \\
\hline HA & Forward 1 & $1-22$ & TGT AAA ACG ACG GCC AGT ATGAAGGCAATACTAGTAGTTCTG \\
\hline HA & Reverse 1 & $901-921$ & CAG GAA ACA GCT ATG ACC GAGGCTGGTGTTTATAGCACC \\
\hline HA & Forward 2 & $802-822$ & TGT AAA ACG ACG GCC AGT CCGAGATATGCATTCGCAATG \\
\hline HA & Reverse 2 & 1676-end & CAG GAA ACA GCT ATG ACC TTAAATACATATTCTACACTGTAGAG \\
\hline NA & Forward 1 & $1-26$ & TGT AAA ACG ACG GCC AGT ATGAATCCAAACCAAAAGATAATAAC \\
\hline NA & Reverse 1 & $823-842$ & CAG GAA ACA GCT ATG ACC CAGGAGCATTCCTCATAGTG \\
\hline NA & Forward 2 & $706-729$ & TGT AAA ACG ACG GCC AGT GGTTCTTGCTTTACTGTAATGACC \\
\hline NA & Reverse 2 & $1386-1410$ & CAG GAA ACA GCT ATG ACC TTACTTGTCAATGGTAAATGGCAAC \\
\hline $\mathrm{NA} \bullet$ & Forward & $727-748$ & CTGTAATGACCGATGGACCAAG \\
\hline $\mathrm{NA} \bullet$ & Reverse & $913-935$ & CAGATTCTGGTTGAAAGACACCC \\
\hline PB1 & Forward 1 & $1-22$ & TGT AAA ACG ACG GCC AGT ATGGATGTCAATCCGACTCTAC \\
\hline PB1 & Reverse 1 & $996-1017$ & CAG GAA ACA GCT ATG ACC CATGCTCAGGATGTTTCTGAAC \\
\hline PB1 & Forward 2 & $597-618$ & TGT AAA ACG ACG GCC AGT GGTCACGCAAAGAACAATAGG \\
\hline PB1 & Reverse 2 & $1521-1542$ & CAG GAA ACA GCT ATG ACC CACTCCAAAGCTGGGTAGCT \\
\hline PB1 & Forward 3 & $1301-1321$ & TGT AAA ACG ACG GCC AGT CAATATACTGGTGGGATGGGC \\
\hline PB1 & Reverse 3 & 2251-end & CAG GAA ACA GCT ATG ACC TTATTTTTGCCGTCTGAGTTCTTC \\
\hline PB2 & Forward 1 & $1-23$ & TGT AAA ACG ACG GCC AGT ATGGAGAGAATAAAAGAACTGAGAG \\
\hline PB2 & Reverse 1 & $998-021$ & CAG GAA ACA GCT ATG ACC CTTTCTTGACTGATGATCCGC \\
\hline PB2 & Forward 2 & $603-626$ & TGT AAA ACG ACG GCC AGT GGTGGCGTACATGCTAGAAAG \\
\hline PB2 & Reverse 2 & $1552-1573$ & CAG GAA ACA GCT ATG ACC CAGTTCCTTGCGTTTCACTGAC \\
\hline PB2 & Forward 3 & $1230-1248$ & TGT AAA ACG ACG GCC AGT GATCAAGGCAGTTAGGGGC \\
\hline PB2 & Reverse 3 & 2258-end & CAG GAA ACA GCT ATG ACC CTAATTGATGGCCATCCGAATTC \\
\hline PA & Forward 1 & $1-23$ & TGT AAA ACG ACG GCC AGT ATGGAAGACTTTGTGCGACAATG \\
\hline PA & Reverse 1 & 996-1017 & CAG GAA ACA GCT ATG ACC CTTCCAAGCCATGAGGTAATTG \\
\hline PA & Forward 2 & $616-36$ & TGT AAA ACG ACG GCC AGT GAGATTACAGGAACTATGCGC \\
\hline PA & Reverse 2 & $1519-1540$ & CAG GAA ACA GCT ATG ACC CATTTCTCAAATGAGACCTTCC \\
\hline PA & Forward 3 & $1162-1184$ & TGT AAA ACG ACG GCC AGT GGAGACCTTAAACAGTATGACAG \\
\hline PA & Reverse 3 & 2130-end & CAG GAA ACA GCT ATG ACC CTACTTCAGTGCATGTGTGAGG \\
\hline M & Forward & $1-21$ & TGT AAA ACG ACG GCC AGT ATGAGTCTTCTAACCGAGGTC \\
\hline M & Reverse & $959-982$ & CAG GAA ACA GCT ATG ACC TTACTCTAGCTCTATGTTGACAAA \\
\hline NP & Forward 1 & $1-20$ & TGT AAA ACG ACG GCC AGT ATGGCGTCTCAAGGCACC \\
\hline NP & Reverse 1 & $801-821$ & CAG GAA ACA GCT ATG ACC GATTTATGTGCAACTGATCCC \\
\hline NP & Forward 2 & $702-721$ & TGT AAA ACG ACG GCC AGT CCAGAGGGCAATGATGGATC \\
\hline NP & Reverse 2 & 1477-end & CAG GAA ACA GCT ATG ACC TCAACTGTCATACTCCTCTGC \\
\hline NS & Forward & $1-20$ & TGT AAA ACG ACG GCC AGT ATGGACTCCAACACCATGTC \\
\hline NS & Reverse & $840-863$ & CAG GAA ACA GCT ATG ACC GTAGAAACAAGGGTGTTTTTTATC \\
\hline
\end{tabular}




\subsection{C11-6' Inhibition Assay}

The C11- $6^{\prime}$ inhibition assay was performed as previously described [44]. A dose range of C11-6' spanning from $1.2 \mu \mathrm{g} / \mathrm{mL}$ to $300 \mu \mathrm{g} / \mathrm{mL}$ was pre-incubated with 0.1 MOI of UTR p9 N09 Stock, OS p9, OS/ $\lambda$ p9, or $\lambda$ p9 for $1 \mathrm{~h}$ in serum-free DMEM at $37^{\circ} \mathrm{C}$. The mix virus plus drug was then inoculated for $1 \mathrm{~h}$ at $37^{\circ} \mathrm{C}$ on a confluent layer of MDCK cells seeded in a 96-well plate. The inocula were then removed and the cells were overlaid with serum-free DMEM containing $1 \%$ penicillin/streptomycin for $12 \mathrm{~h}$ at $37^{\circ} \mathrm{C}$. The number of infected cells was calculated by immunocytochemistry. After fixation in methanol, the primary antibody (mouse monoclonal influenza A antibody 1:100 dilution, Chemicon ${ }^{\circledR}$ ) was added for $1 \mathrm{~h}$ at $37^{\circ} \mathrm{C}$. The cells were then washed with DPBS/Tween $0.05 \%$ three times and the secondary antibody (Anti-mouse IgG, HRP-linked 1:500 dilution, Cell signaling technology) was added. After $1 \mathrm{~h}$, the cells were washed and the DAB solution was added. Infected cells were counted and percentages of infection were calculated by comparing the number of infected cells in treated and untreated conditions. All results are presented as the mean values from two independent experiments performed in duplicate. The EC50 values for inhibition curves were calculated by regression analysis using the program GraphPad Prism version 8.0 (GraphPad Software, San Diego, CA, USA).

\section{Results}

\subsection{Determination of IFN $\lambda 1$ and Oseltamivir Non-Toxic Doses}

In order to assess the antiviral activity of IFN $\lambda 1$ and OS, we first defined their nontoxic dose range by measuring their effect on Calu-3 cells' metabolic activity by MTT Assay. Calu- 3 cells are derived from human bronchial adenocarcinoma and are commonly used as an in vitro model for IV virus infection $[39,45,46]$. They express the TMPRSS2 protease needed for hemagglutinin (HA) maturation and therefore allow for several cycles of IV replication, with no need to add exogenous proteases such as trypsin in the cell culture medium [47]. We evaluated the toxic activity of individual treatments over $48 \mathrm{~h}$ (Figure 1A,B). We chose the dose range of each compound based on previously published data [38]. No toxicity was detected for any of the tested concentrations, as the reduction in cell viability never went below $20 \%$ compared with the untreated control. Then, we assessed the toxicity of IFN $\lambda 1$ plus OS combined with similar dose ranges (Figure 1C). Also this time, no effect on the viability of Calu-3 cells was detected.

\subsection{Susceptibility of $A(H 1 N 1) p d m 09$ Virus to Oseltamivir and IFN $\lambda 1$}

Next, we assessed the antiviral activity of both OS and IFN $\lambda 1$ against $A(H 1 N 1) p d m 09$. A dose range of OS (spanning from $1.8 \mu \mathrm{M}$ to $15 \mu \mathrm{M}$ ) was added to Calu-3 cells in a post-treatment, i.e., administered $1 \mathrm{~h}$ post infection (hpi), right after the inoculum removal. Unlike OS, IFN $\lambda 1$ exerts an antiviral effect only when administered in a pre- plus a post-treatment in cell lines $[38,48]$, as its antiviral effect relies on the activation of a gene expression program, which entails the need for a pre-treatment in vitro. Thus, a dose range of IFN $\lambda 1$ (from $12.5 \mathrm{ng} / \mathrm{mL}$ to $100 \mathrm{ng} / \mathrm{mL}$ ) was administered at both $24 \mathrm{~h}$ before the infection (hbi) and again at $1 \mathrm{hpi}$. The cells were then incubated in a drug-containing medium for $24 \mathrm{~h}$. To quantify the efficacy of the treatments, the number of viral particles present in the supernatant of infected Calu-3 cells at 24 hpi was determined by plaque assay in MDCK cells. We therefore determined the percentage of infectivity by comparing the numbers of viral particles present in each experimental condition to that of the untreated infected control. The drug concentrations that caused either a $50 \%$ or a $90 \%$ decrease in the PFU titer in comparison with control wells without drug were defined as the half maximal effective concentration (EC50) or the effective concentration 90 (EC90), respectively (Figure 2A). Then, following the above-described administration protocol, we verified that IFN $\lambda 1$, though poorly active per se, enhanced the effect of OS in our settings. Specifically, we tested the antiviral activity of the combined dose ranges of the two compounds shown in Figure 2A. At any of the tested combined treatments, the antiviral effect was greater 
than that of OS alone (Figure 2B), confirming a synergistic effect of the two compounds, as published [38].

$\mathbf{A}$
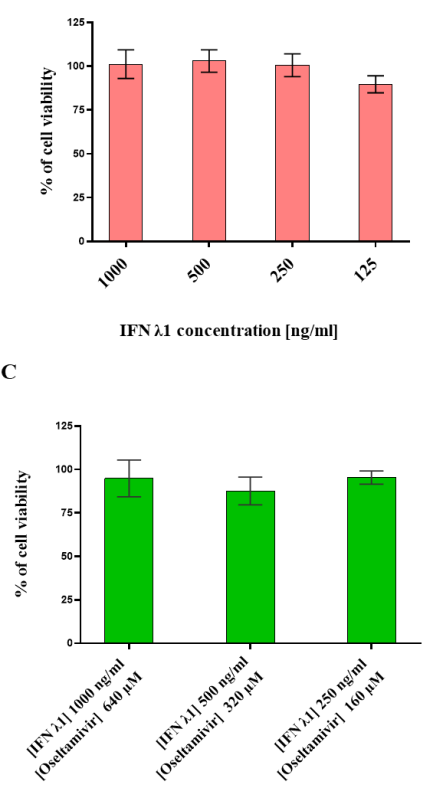

B

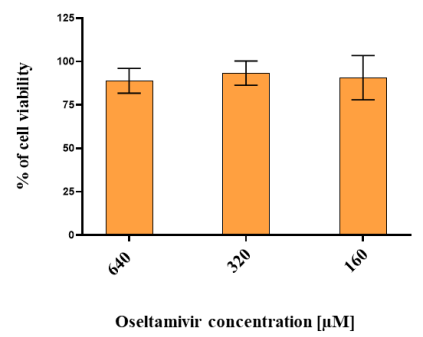

Figure 1. Viability assessment of Calu-3 cells grown in the presence of a dose range of IFN $\lambda 1$ and OS administered alone or in combination. IFN $\lambda 1$ treatment (A), OS treatment (B), IFN $\lambda 1$ plus OS co-treatment (C). Cell viability was measured by MTT assay. The $\%$ of cell viability was calculated based on an untreated control at $48 \mathrm{~h}$ post treatment. The results represent the mean and standard deviation from two independent experiments performed in duplicate. IFN $\lambda 1=$ human IFN $\lambda 1$; OS = Oseltamivir.
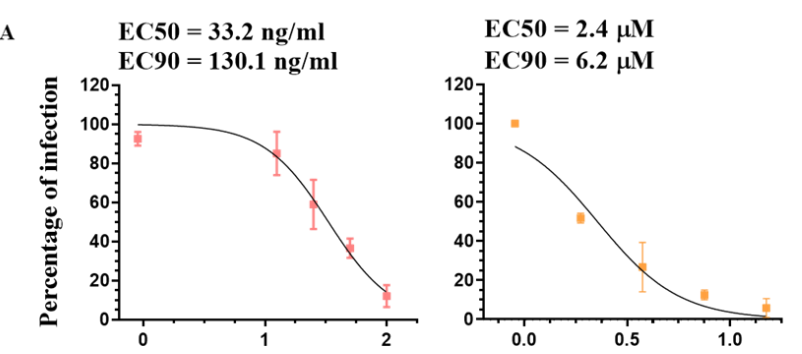

Log IFN $\lambda 1$ concentration $[\mathrm{ng} / \mathrm{ml}] \quad$ Log OS concentration $[\mu M]$

B

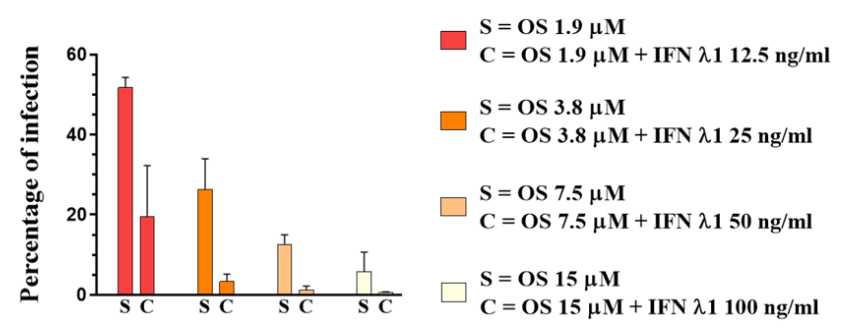

Figure 2. Comparison of IFN $\lambda 1$ and OS antiviral activity against A(H1N1)pdm09 in Calu-3 cells. (A) Dose-response curve of the single treatments. The percentages of infection represent the number of plaques induced by infectious supernatant collected at $24 \mathrm{hpi}$, in treated versus untreated controls. The infection was performed with a MOI of $0.1 \mathrm{PFU} /$ cell. EC50 = Half maximal effective concentration; EC90 = drug concentration at which $90 \%$ of the maximal effect is observed. (B) Bar plot showing the percentages of infection (determined as in A) of a dose range of OS administered individually (S) or of a dose range of OS administered together with a dose range of IFN $\lambda 1$ (C). The results represent the mean and standard deviation from two independent experiments performed in duplicate. 


\subsection{Selection of Resistant Variants against Oseltamivir Administered Alone or in Combination with IFN $\lambda 1$}

IFN $\lambda 1$ and OS display synergistic activity against H1N1 IAV in vitro [38]. However, the question of whether the co-administration of IFN $\lambda 1$ could also increase the barrier to OS resistance has not been investigated yet. To evaluate the effects of the single and combined treatment with OS and IFN $\lambda 1$ on the emergence of A(H1N1)pdm09 resistant variants, we serially passaged the virus 12 times in Calu-3 cells [49,50], in the presence of increasing amounts of OS $(10 \mu \mathrm{M}$ to $640 \mu \mathrm{M})$, IFN $\lambda 1(37 \mathrm{ng} / \mathrm{mL}$ to $1000 \mathrm{ng} / \mathrm{mL})$, or OS plus IFN $\lambda 1$ (Figure 3). The starting concentrations of $37 \mathrm{ng} / \mathrm{mL}$ for IFN $\lambda l$ and $10 \mu \mathrm{M}$ of OS were used at passage $1(\mathrm{p} 1)$ and were doubled at each passage. When the highest non-toxic concentration tested was reached, the dose of the compound was kept constant for the subsequent passages (Figure 3D). At each passage, the cells were infected with a MOI of $0.1 \mathrm{PFU} /$ cell for each condition. Calu- 3 cells were administered with IFN $\lambda 1$ both $24 \mathrm{hbi}$ and $1 \mathrm{hpi}$, while OS was given only at $1 \mathrm{hpi}$. At $48 \mathrm{hpi}$, the infectious viral titers and the plaque size were measured by plaque assay in MDCK cells. Of note, in order to monitor the effects of adaptation of $\mathrm{A}(\mathrm{H} 1 \mathrm{~N} 1) \mathrm{pdm} 09$ to growth in Calu-3 cells, we also passaged the parental virus in parallel in the absence of treatments. Interestingly, we did not observe differences in plaque morphology across conditions at any passage.

Viruses passaged in the presence of OS alone produced titers significantly lower (viral yield reduction $>1 \log$ ) than those of the untreated control (UTR CTRL) at p2, p3, and $\mathrm{p} 4$. However, at $\mathrm{p} 7$ there was no more difference between the titers produced in the presence of OS alone and those generated in the UTR CTRL, suggesting the emergence of an OS-resistant variant (Figure 3A).

Viruses passaged in the presence of IFN $\lambda 1$ alone produced titers not significantly different from those measured in the UTR CTRL (Figure 3B). This result was expected as, due to the lack of innate immune cells, the antiviral activity of IFN $\lambda 1$ in vitro is weak [48], especially if assessed when the viral replication reached its peak (i.e., 48 hpi versus $24 \mathrm{hpi}$ in Figure 2A).

On the other hand, viruses passaged in the presence of OS plus IFN $\lambda 1$ produced titers always lower (except for P4) than those measured in the UTR CTRL, this up to p11. At p12, the treated viruses displayed the same viral titer as the UTR CTRL, indicating a reduced susceptibility to OS. Of note, the emergence of antiviral resistance in the OS condition was observed between $\mathrm{p} 6$ and $\mathrm{p} 7$ (Figure 3A), while in the OS + IFN $\lambda 1$ condition the susceptibility of the viruses to OS was still evident at this passage, and lasted until p11 (Figure $3 \mathrm{C}$ ). This finding strongly suggested that the co-administration of IFN $\lambda 1$ delays the emergence of antiviral resistance to OS.

To confirm the resistance phenotype of the $\mathrm{A}(\mathrm{H} 1 \mathrm{~N} 1) \mathrm{pdm} 09$ variants, we measured their degree of susceptibility to OS and IFN $\lambda 1$. We chose the viruses collected after nine passages (as at $\mathrm{p} 9$ phenotypic resistance had been evident for three passages) in the different conditions and designated as follows: OS p9 (virus passaged nine times in the presence of OS alone), $\lambda \mathrm{p} 9$ (virus passaged nine times in the presence of IFN $\lambda 1$ alone), OS $/ \lambda$ p9 (virus passaged nine times in the presence of OS plus IFN $\lambda 1$ ), and UTR p9 (virus passaged nine times in the absence of selective drug pressure). In parallel, we also tested the $\mathrm{A}(\mathrm{H} 1 \mathrm{~N} 1) \mathrm{pdm} 09$ Stock virus (N09 Stock) produced in MDCK cells and never passaged in Calu-3, to assess whether its sensitivity to the drugs was comparable to that of UTR p9. The dose range of OS (from $10 \mu \mathrm{M}$ to $640 \mu \mathrm{M}$ ) was administered $1 \mathrm{hpi}$, while that of IFN $\lambda 1$ (from $37 \mathrm{ng} / \mathrm{mL}$ to $1000 \mathrm{ng} / \mathrm{mL}$ ) was given at $24 \mathrm{hbi}$ plus at $1 \mathrm{hpi}$. After $24 \mathrm{~h}$, the number of infectious viral particles released in the supernatant was determined by plaque assay in MDCK and the EC50 value was calculated in comparison to infected control wells without drug. 
$\mathbf{A}$

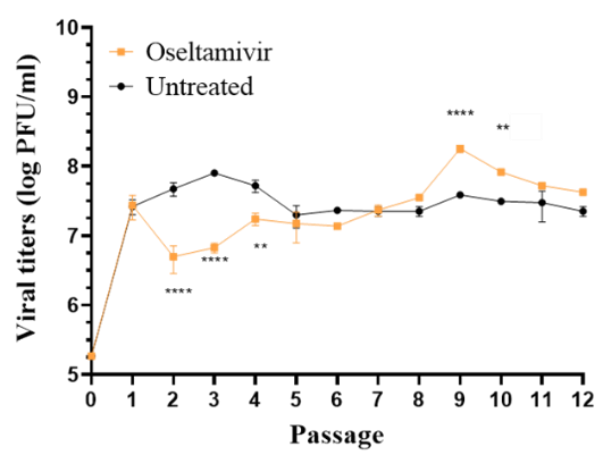

C

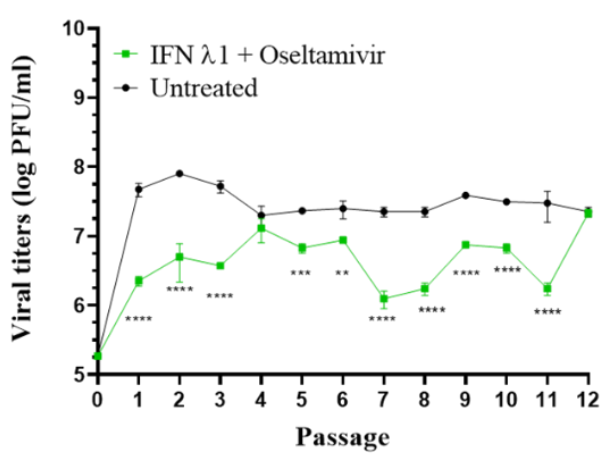

B
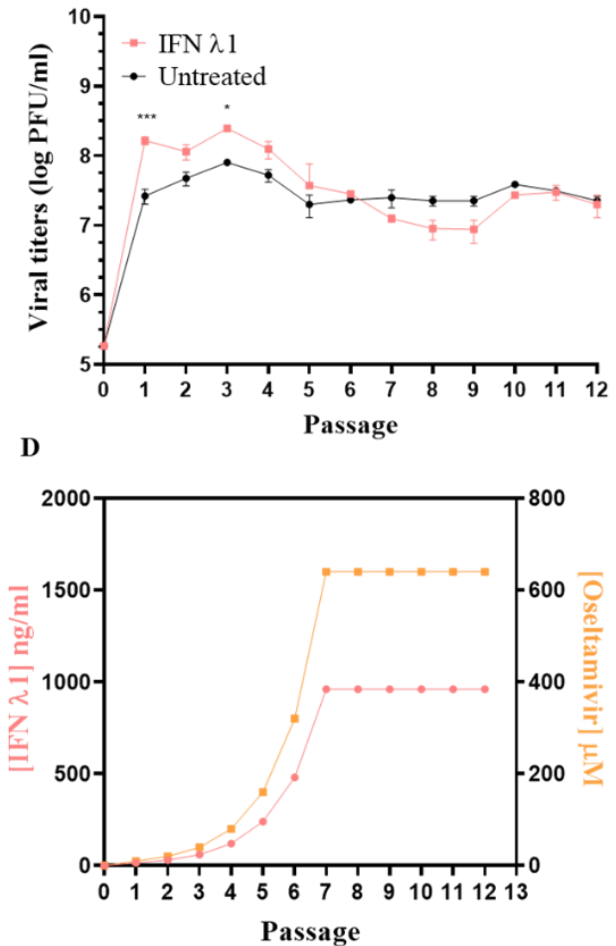

Figure 3. Comparison of viral titers from viral supernatants collected from Calu-3 cells infected with $\mathrm{A}(\mathrm{H} 1 \mathrm{~N} 1) \mathrm{pdm} 09$ for $48 \mathrm{~h}$ in the presence of increasing concentrations of OS (A), IFN $\lambda 1$ (B), and OS plus IFN $\lambda 1(\mathbf{C})$, this over 12 consecutive passages in Calu-3 cells. Each population is shown together with the untreated control, serially passaged in the absence of selective drug pressure. The titer (performed in MDCK cells) is expressed in plaque-forming units per milliliter (log PFU/mL). The drug concentration at each passage is also shown (D). The results represent the mean and standard deviation from two independent titrations. ${ }^{*}, p \leq 0.05 ;{ }^{* *}, p \leq 0.01 ; * * *, p \leq 0.001 ;{ }^{* * * *}, p \leq 0.0001$.

As expected, OS p9 was resistant to OS, with a shift in the EC50 by a factor of two orders of magnitude compared with the UTR or N09 Stock (Figure 4A). On the contrary, OS/ $\lambda$ p9 displayed a level of susceptibility similar to that of the UTR or N09 stock, further confirming that the resistance against OS did not emerge when the drug was co-administered with IFN $\lambda 1$ (Figure 4A). All variants were sensitive to IFN $\lambda 1$ in a dose-dependent manner (Figure 4B). The EC50 against UTR p9 was increased by 1.8 fold compared with the N09 stock. However, this difference was not significant and was probably determined by the viral adaptation to Calu- 3 cells (see below). The EC50 $\lambda$ p9 was increased by 2.5 fold compared with the N09 Stock, but also this change was not significant (Figure 4B). Lastly, there was no significant difference between $\lambda$ p 9 and UTR p 9 , at any of the tested doses of IFN $\lambda 1$, suggesting that no resistance vs. IFN $\lambda 1$ emerged. This finding is in line with previously published data showing that IAVs can develop resistance to type III interferons in vitro after $>20$ passages in Calu-3 cells [48]. 
A

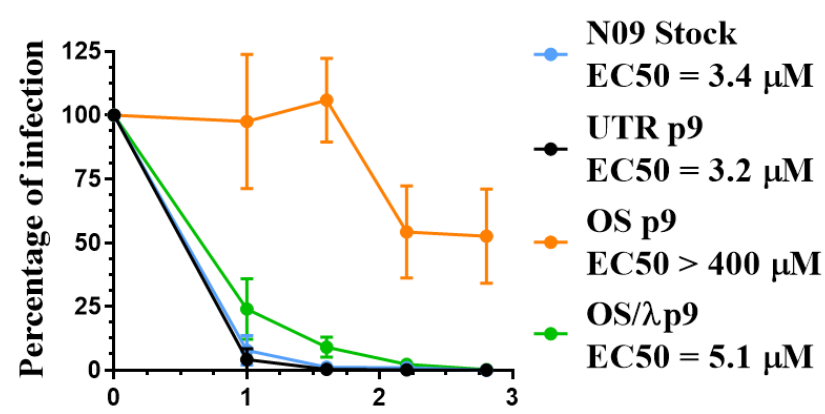

Log Oseltamivir concentration $[\mu \mathrm{M}]$
B

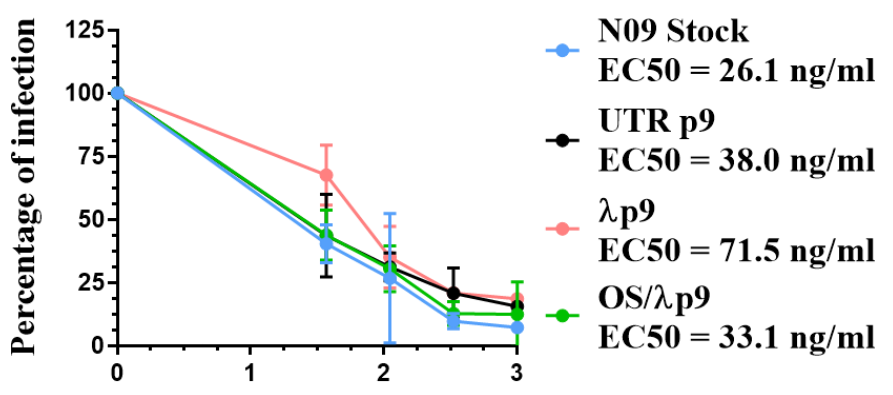

$\log$ IFN $\lambda 1$ concentration $[\mathrm{ng} / \mathrm{ml}]$

Figure 4. Antiviral effect of OS (A) and IFN $\lambda 1$ (B) against the A(H1N1)pdm09 variants grown for nine passages in Calu-3 cells and measured by a virus yield reduction assay in MDCK cells. Mean EC50 values and standard deviations were calculated from two independent experiments performed in duplicate. OS p9 = virus passaged nine times in the presence of OS alone; $\lambda \mathrm{p} 9=$ virus passaged nine times in the presence of IFN $\lambda 1$ alone; OS $/ \lambda \mathrm{p} 9=$ virus passaged nine times in the presence of OS plus IFN $\lambda 1$; UTR p $9=$ virus passaged nine times in the absence of selective drug pressure; N09 Stock = virus produced in MDCK cells and never passaged in Calu-3.

\subsection{Viral Fitness Assessment of the A(H1N1)pdm09 Variants In Vitro and Ex Vivo}

The titers of the OS variant after p8 were significantly higher compared with the UTR (Figure 3A); however, gain-of-resistance is often associated with loss of viral fitness [51]. We thus determined the growth kinetics of N09 Stock, OS p9, $\lambda$ p9, OS/ $\lambda$ p9, and UTR p9 strains at 24, 48, and 72 hpi in Calu-3 cells. We did not observe any significant difference across the variants, confirming that the acquisition of OS resistance does not result in a loss of fitness (Figure 5A).

A

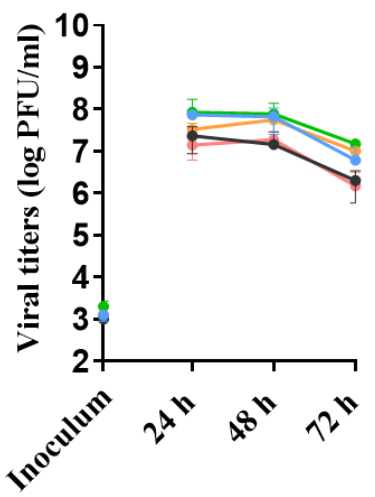

B

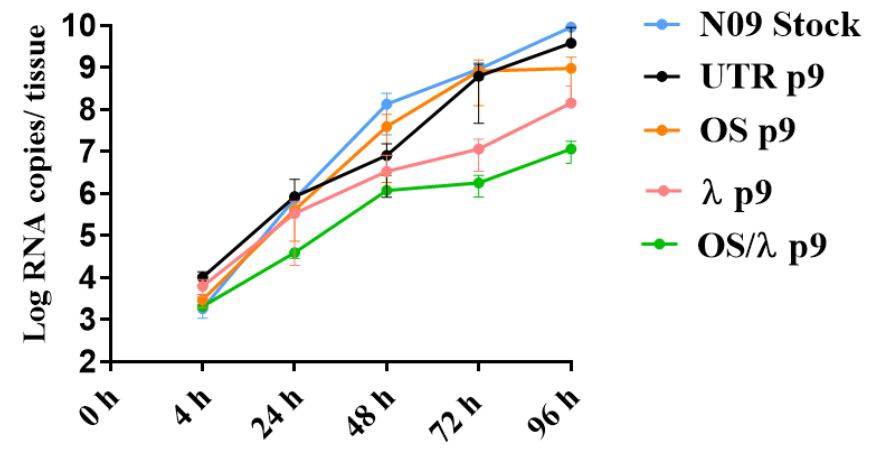

Figure 5. Replication of the A(H1N1)pdm09 variants in Calu-3 cells (A) and in ex vivo human airway epithelia reconstituted at the air-liquid interface (B). In (A) Calu-3 cells were infected with a MOI of $0.01 \mathrm{PFU} /$ cell and viral titers were measured by plaque assay from daily collected cell supernatants. At each time point, the entire infectious supernatant was collected and new medium was added, thus allowing for the measurement of daily viral production. In (B), Mucilair respiratory tissues were infected apically with $5 \times 10^{4} \mathrm{PFU}$, determined by plaque assay in MDCK cells, per tissue. Viral loads, expressed in RNA copies/tissue, were quantified by RT-qPCR from daily collected apical. The residual virus present on the apical side of the tissues upon the inoculum removal, at 4 hpi, was also quantified by RT-qPCR. Statistical significance described in the text is not shown in the figure for clarity. Abbreviations as in Figure 4. The results represent the mean and standard deviation from two independent experiments performed in duplicate.

To validate these results in a more relevant culture model, we performed another fitness assay in Mucilair. Mucilair tissues are human airway epithelia reconstituted in vitro 
from cells isolated from the respiratory tract of healthy donors. They consist of ciliated, goblet, and basal cells cultured at the air-liquid interface in a 3D structure. Mucilair perfectly recapitulates the barrier functions and mucociliary responses of the respiratory mucosa and it represents an ideal model to study respiratory viruses [51-53]. We thus infected Mucilair tissues with the same infectious doses of each variant on their apical side at $33{ }^{\circ} \mathrm{C}$ to simulate an upper respiratory infection. Then, we monitored the viral growth over time, collecting the virus released apically every $24 \mathrm{~h}$. Overall, the N09 stock grew similarly to OS p9 and UTR p9 (Figure 5B), indicating that neither viral adaptation to Calu-3 cells, nor the OS resistance, affected viral fitness in Mucilair. OS $/ \lambda \mathrm{p} 9$ and $\lambda \mathrm{p} 9$ displayed a similar kinetic and grew slower than the N09 Stock $(p<0.05$ at 48, 72, and 96 hpi for both $\lambda$ p9 and OS/ $\lambda$ p9), suggesting that IFN $\lambda 1$ and the combined treatment selective pressure in Calu-3 cells impact the fitness of $\mathrm{A}(\mathrm{H} 1 \mathrm{~N} 1)$ pdm09 when grown in reconstituted human airway epithelia.

\subsection{Sequence Analysis of Selected A(H1N1)pdm09 Variants}

We next sequenced the entire genome of all the variants generated at $\mathrm{p} 9$, together with the N09 Stock (Table 2). The H275Y mutation, known to confer resistance to OS [54], was found in the NA segment of the variant passaged nine times in presence of OS, but not in $\lambda$ p9 or OS/ $\lambda$ p9 (Table 2). In addition, the NA of all analyzed variants and of the original viral stock contained D344N and D354G, both permissive mutations necessary for maintaining full NA function in the presence of H275Y [55] (Table 2). H275Y decreases NA surface expression while D344N and D354G allow the viruses to tolerate this defect by altering, respectively, enzyme affinity and activity, thus restoring viral fitness [12,56]. We also sequenced earlier passages of the OS variant to document the time of occurrence of H275Y. We started to detect the mutation in the NA segment of OS p7 (but not in OS p6) as a minor quasi-species, which slightly increased at $\mathrm{p} 8$ to become the majority population at P9. Considering that the sensitivity of detection for Sanger sequencing is estimated to be approximately $15 \%$ to $20 \%$ of the mutant allele frequency, we estimated that OS administered as a single treatment induced the emergence of H275Y between p6 and p7. To define to which extent IFN $\lambda 1$ co-administration delayed the resistance emergence, we also sequenced the NA gene of OS/ $\lambda$ p10, 11, and 12 (Table 2). H275Y appeared as a minor population in OS $/ \lambda \mathrm{p} 10$, became more represented at $\mathrm{p} 11$, and then became dominant at p12, which correlates well with the viral yield of OS $/ \lambda$ p12 (Figure $3 C$ ). These results demonstrate that IFN $\lambda$ co-administration delayed the emergence of the dominant H725Y by three passages, from p 9 (in the OS single treatment condition) to p12 (in the OS/ $\lambda$ combined treatment condition), even in the presence of permissive mutations that facilitate its occurrence. Interestingly, we highlighted three amino acid substitutions, K62R, G239D, and Q240R, in the HA segment of UTR p9 and $\lambda$ p9 variants (Table 2). All these mutations occurred in the HA globular head [57]. More specifically, Q240R lies in the HA receptor binding site and seems to be associated with a preference for alpha 2,3 rather than alpha 2,6 sialic acid receptors [58]. As they were only found in the UTR p 9 and in the $\lambda \mathrm{p} 9$ variants, we surmised that these mutations resulted from the adaptation of the virus to Calu- 3 cells, whose surface sialic acid differs from that of the MDCK cells used to produce the stock virus [59]. We therefore investigated the speed of emergence of these HA mutations in UTR p9 and we found that they occurred upon only four passages in Calu-3 cells (Table 2). Lastly, we identified other substitutions, all present as a mixed population, in the PA, PB1, PB2, NP, and M segments of the UTR p9, $\lambda$ p9, OS p9, and OS $\lambda$ p9 variants (Table 2). These mutations were not all represented in each variant, except for K57R (M segment), which probably resulted from viral adaptation to Calu-3 cells (Table 2). Moreover, to the best of our knowledge, they are either not reported in the literature, or not associated with a specific phenotype. 
Table 2. Amino acid changes identified by sanger sequencing in selected $\mathrm{A}(\mathrm{H} 1 \mathrm{~N} 1) \mathrm{pdm} 09$ variants.

\begin{tabular}{|c|c|c|c|c|c|c|c|c|c|c|}
\hline Virus & $\begin{array}{l}\text { Passage } \\
\text { No. }\end{array}$ & $\begin{array}{l}\text { Oseltamivir } \\
\quad(\mu \mathrm{M})\end{array}$ & $\begin{array}{l}\text { IFN } \lambda 1 \\
\text { (ng/mL) }\end{array}$ & HA * & NA ** & PA & PB1 & PB2 & NP & $\mathbf{M}$ \\
\hline $\begin{array}{l}\text { N09 } \\
\text { Stock }\end{array}$ & - & - & - & - & D344N, D354G & - & - & - & - & - \\
\hline UTR p3 & 3 & - & - & $\begin{array}{c}- \\
\text { K62R, }\end{array}$ & D344N, D354G & ns & ns & ns & ns & ns \\
\hline UTR p4 & 4 & - & - & $\begin{array}{l}\text { G239D, } \\
\text { Q240R } \\
\text { K62R, }\end{array}$ & D344N, D354G & ns & ns & ns & ns & ns \\
\hline UTR p9 & 9 & - & - & $\begin{array}{l}\text { G239D, } \\
\text { Q240R }\end{array}$ & D344N, D354G & $\mathrm{V} 100 \mathrm{~L}$ & $\mathrm{~A}^{1920 \mathrm{~T}^{\circ}}$ & T303S • & - & $\mathrm{K} 57 \mathrm{R}$ \\
\hline OS p7 & 7 & 640 & - & ns & $\mathrm{H} 275 \mathrm{Y}$, D344N, D354G & ns & ns & ns & ns & ns \\
\hline OS p8 & 8 & 640 & - & ns & $\mathrm{H} 275 \mathrm{Y} \cdot \mathrm{D} 344 \mathrm{~N}, \mathrm{D} 354 \mathrm{G}$ & ns & ns & ns & ns & ns \\
\hline OS p9 & 9 & 640 & - & $\begin{array}{c}- \\
K 62 R\end{array}$ & H275Y, D344N, D354G & $\mathrm{N} 65 \mathrm{~K}$ & - & - & - & $\mathrm{K} 57 \mathrm{R} \cdot$ \\
\hline$\lambda \mathrm{p} 9$ & 9 & - & 960 & $\begin{array}{l}\text { No211, } \\
\text { G239D, } \\
\text { Q240R }\end{array}$ & D344N, D354G & - & - & $\mathrm{I} 57 \mathrm{M}$ • & $\mathrm{P} 318 \mathrm{Q}$ • & $\mathrm{K} 57 \mathrm{R}$ - \\
\hline OS $/ \lambda \mathrm{p} 9$ & 9 & 640 & 960 & - & D344N, D354G & - & - & - & - & $\mathrm{K} 57 \mathrm{R}$ \\
\hline $\begin{array}{c}\text { OS/ } \lambda \\
\text { p10 }\end{array}$ & 10 & 640 & 960 & ns & $\mathrm{H} 275 \mathrm{Y} \bullet, \mathrm{D} 344 \mathrm{~N}, \mathrm{D} 354 \mathrm{G}$ & ns & ns & ns & ns & ns \\
\hline $\begin{array}{l}\text { OS/ } / \lambda \\
\text { p11 }\end{array}$ & 11 & 640 & 960 & ns & $\mathrm{H} 275 \mathrm{Y} \bullet, \mathrm{D} 344 \mathrm{~N}, \mathrm{D} 354 \mathrm{G}$ & ns & ns & ns & ns & ns \\
\hline $\begin{array}{l}\text { OS } / \lambda \\
\text { p12 }\end{array}$ & 12 & 640 & 960 & ns & $\mathrm{H} 275 \mathrm{Y} \cdot \mathrm{D} 344 \mathrm{~N}, \mathrm{D} 354 \mathrm{G}$ & ns & ns & ns & ns & ns \\
\hline
\end{tabular}

${ }^{*}$ Based on $\mathrm{H} 1$ numbering as in [60]. ${ }^{* *}$ Based on N1 numbering as in [61]. ${ }^{-}$Present as a mixed population. ${ }^{\circ}$ Silent mutation, for which the nucleotide substitution is shown. $\mathrm{ns}=$ not sequenced.

\subsection{Effect of HA Changes on Receptor Specificity}

To evaluate the effect of the K62R, G239D, and Q240R HA1 mutations on HA binding properties, we examined the affinity of all our $\mathrm{A}(\mathrm{H} 1 \mathrm{~N} 1) \mathrm{pdm} 09$ variants to $\mathrm{C} 11-6^{\prime}$, a virucidal compound exposing a residue of $6^{\prime}$ SLN (6'sialyl-N-acetyllactosamine), which specifically binds H1N1 HA, thus inducing the inactivation of extracellular viral particles [44]. To assess the receptor specificity of HA independently of any bias introduced by the host cell, we first pre-incubated a dose range of C11- $6^{\prime}$ with a fixed amount of virus (corresponding to a MOI of $0.1 \mathrm{PFU} /$ cell). Then, we inoculated the mixed virus plus compound on MDCK cells and determined the number of infected cells by immunohistochemistry upon one cycle of viral replication. The N09 Stock, OS p9, and OS $\lambda$ p9, which did not bear K62R, G239D, or Q240R, were sensitive to C11- $6^{\prime}$ to the same extent, with similar EC50 values (Figure 6). On the other hand, C11-6 did not prevent the infection of UTR p9 and $\lambda$ p9 variants, and the EC50 value against these variants was two orders of magnitude larger than the one measured against the N09 Stock (Figure 6). These data suggest that K62R, G239D, and Q240R, which emerged during repeated passages in Calu3 cells, shifted the sialic acid preference of the viruses. Of note, these mutations did not appear under the selective pressure of OS, but they occurred despite the presence of IFN $\lambda 1$. 


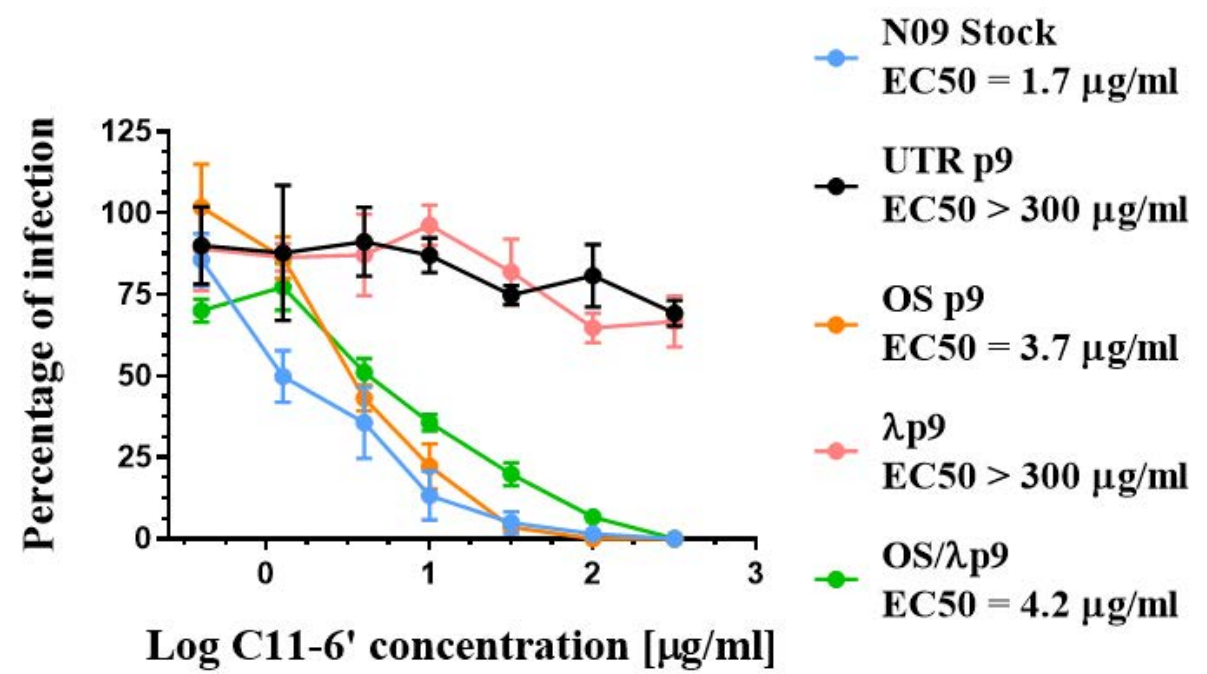

Figure 6. Dose-response curves demonstrating the antiviral activity of C11- $6^{\prime}$ when pre-incubated with $\mathrm{A}(\mathrm{H} 1 \mathrm{~N} 1) \mathrm{pdm} 09$ variants before infection in MDCK cells. OS $\mathrm{p} 9=$ virus passaged nine times in the presence of OS alone; $\lambda$ p $9=$ virus passaged nine times in the presence of IFN $\lambda 1$ alone; OS $/ \lambda$ p $9=$ virus passaged nine times in the presence of OS plus IFN $\lambda 1$; UTR $p 9=$ virus passaged nine times in the absence of selective drug pressure; N09 Stock = virus produced in MDCK cells and never passaged in Calu-3. Mean EC50 values and standard deviations were calculated from two independent experiments performed in duplicate.

\section{Discussion}

Rapidly acquired genetic variability has made rational drug design against IVs extremely hard. The problem underlying this challenge is the inevitable development of drug resistance, where changes in a very small number of amino acid residues in the targeted viral protein are sufficient to reduce or abolish the efficacy of the drug. NAIs provide the front line of defense against IV infection and the response to the next influenza pandemic will probably rely on the extensive use of this class of antivirals, combined with other transmission control measures [62]. However, since resistant variants can arise either naturally or as a result of drug administration, it is very likely that the use of NAIs on the scale anticipated for the control of pandemic influenza will create a unique selective pressure for the emergence and spread of resistant strains [63]. There is an unmet need for new treatment regimens that can reduce the risk of resistance appearance.

Combination therapy with compounds having different mechanisms of action is a possible option for influenza treatment. In this work, we assessed the effectiveness of OS, combined with IFN $\lambda 1$, against the emergence of $\mathrm{A}(\mathrm{H} 1 \mathrm{~N} 1) \mathrm{pdm} 09$ drug-resistant variants in Calu-3 cells. We found that, in line with the literature, OS administered as a single drug effectively reduced viral replication until passage 4 , but rapidly induced the emergence of $\mathrm{H} 275 \mathrm{Y}$ in the NA gene, which started between passages 6 and 7. This mutation became dominant at passage 9 and was associated with a significantly reduced susceptibility to OS, with an increase in the EC50 by two orders of magnitude. The antiviral effect of IFN $\lambda 1$ was weak, as the titers generated at each passage were substantially similar to those produced in the UTR condition and, accordingly, the drug alone did not induce the emergence of resistance after twelve passages. Nonetheless, when OS was co-administered with IFN $\lambda 1, \mathrm{H} 275 \mathrm{Y}$ did not appear at $\mathrm{p} 7$ but emerged only at $\mathrm{p} 10$. The OS/ $\lambda \mathrm{p} 9$ was susceptible to OS to the same extent as the N09 Stock, UTR p9, and $\lambda$ p9 variants. H275Y hinders viral replication and its spread is made possible by several compensatory mutations that restore viral fitness [55]. Two of these amino acid substitutions, D344N and D354G, were present in all our variants, including the stock virus. D344N was identified as a major determinant of increased NA affinity for sialic acids, while D354G increases the activity of the enzyme and can compensate alone for the remaining H275Y-generated functional defects [55,64]. Both mutations are present in currently circulating H1N1 strains. This result emphasizes 
the delayed emergence of OS resistance in the presence of IFN $\lambda 1$ co-administration, even in strains that are tolerant to H275Y. Importantly, H275Y is the major but not the only mutation known to confer resistance to OS. I223V and S247N have also been observed alone or in combination with H275Y [65] in the NA segment of resistant 2009 pandemic H1N1 viruses, but none of these additional substitutions appeared in the OS p9 variant.

OS resistance in the H1N1pdm09 results in an increased viral infectiousness [66]. Of note, in Calu-3 cells, we did not observe any difference in the kinetic of viral replication between the variants generated in the same cell line and the N09 Stock produced in MDCK cells and OS resistance did not impact viral fitness. Similarly, in ex vivo reconstituted respiratory tissues, OS p9, UTR p9, and the N09 Stock replicated with a similar kinetic, but significantly faster compared with $\lambda \mathrm{p} 9$ and OS $/ \lambda \mathrm{p} 9$. This suggests that OS resistance does not impact viral fitness in respiratory tissues.

To monitor the emergence of amino acid substitutions induced by the adaptation of the WT virus to growth in Calu-3 cells, we passaged the parental virus in parallel in the absence of any antiviral selective pressure. Three HA mutations, K62R, G239D, and Q240R, were found in the HA globular head [57] of UTR p9 and $\lambda p 9$ variants and resulted in a reduced binding affinity for the $6^{\prime}$ SLN-thrisaccharide, as shown by the lack of susceptibility towards C11-6 $6^{\prime}[29,44]$. These amino acid substitutions are a consequence of the viral adaptation to Calu-3 cells and occur upon four passages in this cell line. It is not clear why these mutations did not confer a proliferative advantage in Calu-3 cells over the N09 Stock and why they did not affect viral fitness in Mucilair. Additionally, none of them appeared in the OS or the OS $/ \lambda$ p9 variant, probably due to the OS selective pressure limiting viral replication and emergence of resistance. This finding poses the issue of the choice of the in vitro model when evaluating the effectiveness of an antiviral. The occurrence of K62R, G239D, and Q240R in Calu-3 does not bias the assessment of IV susceptibility to NAI, but it might jeopardize the study of other classes of antivirals, namely those targeting the HA receptor binding domain. Sequencing analysis detected additional non-conservative and previously undescribed mutations in PA (V100L and N65K), PB2 (T303S and I57M), NP (P318Q), and $\mathrm{M}$ (K57R) segments of the variants generated at p9. Besides K57R, these mutations were not equally distributed across the viral strains. Nonetheless, their presence and distribution could not explain the differences in viral fitness in Mucilair between the N09 Stock and the two variants OS $/ \lambda$ p9 and $\lambda$ p9. Sequencing tools more accurate than the Sanger method, such as NGS technologies, would be needed to better profile the genetic features of these viral strains and the association with different viral fitness ex vivo.

The findings presented in this study support the prospective therapeutic application of a combined OS/IFN $\lambda 1$ treatment against influenza infection. IFN $\lambda 1$ impaired viral replication at multiple levels, thus preventing the occurrence of H275Y. In our settings, the combinatorial effect of the two compounds was investigated upon twelve passages in the presence of drugs. Additional studies will be needed to precisely estimate to which extent IFN $\lambda 1$ can delay the emergence of OS resistance in vivo. Calu- 3 cells respond to IV infection by inducing an IFN response [46], which is however not sufficient to prevent the emergence of OS-resistant strains. Studies in B6.A2G-Mx1 mice demonstrated that IFN $\lambda$, administered intranasally and upon infection, is a potent anti-influenza therapeutic without the inflammatory side effects of IFN $\alpha$ treatment, suggesting IFN $\lambda$ as a potential treatment of choice against IV $[32,38,67]$. Further in vivo studies will be necessary to investigate whether IFN $\lambda$ will be synergistic with OS and delay the emergence of resistance, thus extending the OS treatment window. In addition, similar studies combining IFN $\lambda$ with other anti-IV antivirals known to induce viral resistance, such as baloxavir [68], should be performed to find out whether a similar delay in resistance emergence is observed. Another lesson that can be drawn from our work is that caution should be exercised when selecting in vitro models to test antivirals against IV.

Author Contributions: Conceptualization, C.M., A.C.-A.Z., and C.T.; Methodology, C.M., A.C.-A.Z., P.J.S., S.C., and S.H.; Validation, C.M. and A.C.-A.Z.; Investigation, C.M. and A.C.-A.Z.; Resources, C.T. and F.S.; Data curation, C.M., A.C.-A.Z., and C.T.; Writing-original draft preparation, C.M; 
Writing-review and editing, all authors.; Supervision, C.T.; Project administration, C.T.; Funding acquisition, C.M., C.T., and F.S. All authors have read and agreed to the published version of the manuscript.

Funding: This work was supported by the Swiss National Science Foundation (Sinergia grant CRSII5_180323 to F.S. and C.T.) and by the Fondation Aclon (Geneva, to C.T.).

Acknowledgments: We would like to thank Mirco Schmolke (University of Geneva) for providing us with $\mathrm{A}(\mathrm{H} 1 \mathrm{N1})$ pdm09 and the primers used for HA and NA sequencing.

Conflicts of Interest: The authors declare no conflict of interest. The funders had no role in the design of the study; in the collection, analyses, or interpretation of data; in the writing of the manuscript; or in the decision to publish the results.

$\begin{array}{ll}\text { Abbreviations } & \\ \text { MDCK } & \text { Mardin-Darby Canine Kidney cells } \\ \text { Calu-3 } & \text { Human sub-mucosal cell line derived from lung adenocarcinoma } \\ \text { DMEM } & \text { Dulbecco's Modified Eagle's-Medium } \\ \text { MEM } & \text { Minimum Essential Medium Eagle } \\ \text { A(H1N1)pdm09 } & \text { Influenza A/Netherlands /602/2009 virus } \\ \text { NA } & \text { Neuraminidase } \\ \text { HA } & \text { Hemagglutinin } \\ \text { PFU } & \text { Plaque forming unit } \\ \text { IV } & \text { Influenza virus } \\ \text { IAV } & \text { Influenza A virus } \\ \text { IBV } & \text { Influenza B virus } \\ \text { MOI } & \text { Multiplicity of infection } \\ \text { IFN } & \text { Interferon } \\ \text { OS } & \text { Oseltamivir } \\ \text { N09 Stock } & \text { A/Netherlands } / 602 / 2009 \text { stock virus produced in MDCK cells } \\ \text { UTR p9 } & \text { Variant passaged } 9 \text { times without drug in Calu-3 cells } \\ \text { UTR p3 } & \text { Variant passaged } 3 \text { times without drug in Calu-3 cells } \\ \text { UTR p4 } & \text { Variant passaged } 4 \text { times without drug in Calu-3 cells } \\ \text { OS p9 } & \text { Variant passaged 9 times with increasing doses of OS in Calu-3 cells } \\ \text { OS p8 } & \text { Variant passaged } 8 \text { times with increasing doses of OS in Calu-3 cells } \\ \Lambda \text { p9 } & \text { Variant passaged 9 times with increasing doses of IFN } \lambda 1 \text { in Calu-3 cells } \\ \lambda / O S & \text { p9 Variant passaged } 9 \text { times with increasing doses of OS plus IFN } \lambda 1 \text { in Calu-3 cells } \\ \lambda \text { p9 } & \text { Variant passaged } 9 \text { times with increasing doses of IFN } \lambda 1 \text { in Calu-3 cells } \\ 6^{\prime S} \text { SN } & \text { 6'sialyl-N-acetyllactosamine } \\ \text { C11-6' } & \text { Virucidal nanomaterial based on a } \beta \text {-cyclodextrin core, exposing } 6{ }^{\prime} S L N \\ \text { Hpi } & \text { Hours post infection } \\ \text { Hbi } & \text { Mours before infection } \\ \text { EC50 } & \text { RNA-dependent RNA polymerase } \\ \text { RdRp } & p \text { value } \\ p & \\ & \end{array}$

\section{References}

1. Paget, J.; Spreeuwenberg, P.; Charu, V.; Taylor, R.J.; Iuliano, A.D.; Bresee, J.; Lone, S.; Cecile, V. Global mortality associated with seasonal influenza epidemics: New burden estimates and predictors from the GLaMOR Project. J. Glob. Health 2019, 9, 020421. [CrossRef]

2. Long, J.S.; Mistry, B.; Haslam, S.M.; Barclay, W.S. Host and viral determinants of influenza A virus species specificity. Nat. Rev. Microbiol. 2019, 17, 67-81. [CrossRef] [PubMed]

3. Saunders-Hastings, P.R.; Krewski, D. Reviewing the History of Pandemic Influenza: Understanding Patterns of Emergence and Transmission. Pathogens 2016, 5, 66. [CrossRef]

4. Lampejo, T. Influenza and antiviral resistance: An overview. Eur. J. Clin. Microbiol. Infect. Dis. 2020, 39, 1201-1208. [CrossRef] [PubMed]

5. Hayden, F.G.; de Jong, M.D. Emerging influenza antiviral resistance threats. J. Infect. Dis. 2011, 203, 6-10. [CrossRef] [PubMed]

6. Hay, A.J.; Wolstenholme, A.J.; Skehel, J.J.; Smith, M.H. The molecular basis of the specific anti-influenza action of amantadine. EMBO J. 1985, 4, 3021-3024. [CrossRef] [PubMed] 
7. Bright, R.A.; Medina, M.J.; Xu, X.; Perez-Oronoz, G.; Wallis, T.R.; Davis, X.M.; Povinelli, L.; Cox, N.I.; Klimov, A.I. Incidence of adamantane resistance among influenza A (H3N2) viruses isolated worldwide from 1994 to 2005: A cause for concern. Lancet 2005, 366, 1175-1181. [CrossRef]

8. Hurt, A.C.; Holien, J.K.; Parker, M.; Kelso, A.; Barr, I.G. Zanamivir-resistant influenza viruses with a novel neuraminidase mutation. J. Virol. 2009, 83, 10366-10373. [CrossRef]

9. L'Huillier, A.G.; Abed, Y.; Petty, T.J.; Cordey, S.; Thomas, Y.; Bouhy, X.; Schibler, M.; Simon, A.; Chalandon, Y.; van Delden, C.; et al. E119D Neuraminidase Mutation Conferring Pan-Resistance to Neuraminidase Inhibitors in an A(H1N1)pdm09 Isolate From a Stem-Cell Transplant Recipient. J. Infect. Dis. 2015, 212, 1726-1734. [CrossRef]

10. Laborda, P.; Wang, S.Y.; Voglmeir, J. Influenza Neuraminidase Inhibitors: Synthetic Approaches, Derivatives and Biological Activity. Molecules 2016, 21, 1513. [CrossRef]

11. Abed, Y.; Pizzorno, A.; Bouhy, X.; Boivin, G. Role of permissive neuraminidase mutations in influenza A/Brisbane/59/2007-like (H1N1) viruses. PLoS Pathog. 2011, 7, e1002431. [CrossRef]

12. Bloom, J.D.; Gong, L.I.; Baltimore, D. Permissive secondary mutations enable the evolution of influenza oseltamivir resistance. Science 2010, 328, 1272-1275. [CrossRef] [PubMed]

13. Baranovich, T.; Saito, R.; Suzuki, Y.; Zaraket, H.; Dapat, C.; Caperig-Dapat, I.; Oguma, T.; Ibrahim Shabana, I.; Saito, T.; Suzuki, T. Emergence of H274Y oseltamivir-resistant A(H1N1) influenza viruses in Japan during the 2008-2009 season. J. Clin. Virol. 2010, 47, 23-28. [CrossRef]

14. Kossyvakis, A.; Mentis, A.A.; Tryfinopoulou, K.; Pogka, V.; Kalliaropoulos, A.; Antalis, E.; Lytras, T.; Meijer, A.; Tsiodras, S.; Karakitsos, P.; et al. Antiviral susceptibility profile of influenza A viruses; keep an eye on immunocompromised patients under prolonged treatment. Eur. J. Clin. Microbiol. Infect. Dis. 2017, 36, 361-371. [CrossRef] [PubMed]

15. Leang, S.K.; Deng, Y.M.; Shaw, R.; Caldwell, N.; Iannello, P.; Komadina, N.; Buchy, F.; Chittaganpitch, M.; Dwyer, D.E.; Fagan, P.; et al. Influenza antiviral resistance in the Asia-Pacific region during 2011. Antivir. Res. 2013, 97, 206-210. [CrossRef] [PubMed]

16. Okomo-Adhiambo, M.; Nguyen, H.T.; Abd Elal, A.; Sleeman, K.; Fry, A.M.; Gubareva, L.V. Drug susceptibility surveillance of influenza viruses circulating in the United States in 2011-2012: Application of the WHO antiviral working group criteria. Influenza Other Respir. Viruses 2014, 8, 258-265. [CrossRef]

17. Bragstad, K.; Hungnes, O.; Litleskare, I.; Nyrerod, H.C.; Dorenberg, D.H.; Hauge, S.H. Community spread and late season increased incidence of oseltamivir-resistant influenza A(H1N1) viruses in Norway 2016. Influenza Other Respir. Viruses 2019, 13, 372-381. [CrossRef]

18. Hashem, A.M.; Azhar, E.I.; Shalhoub, S.; Abujamel, T.S.; Othman, N.A.; Al Zahrani, A.B.; Abdullah, H.M.; Al-Alawi, M.M.; A Sindi, A.A. Genetic characterization and diversity of circulating influenza A/H1N1pdm09 viruses isolated in Jeddah, Saudi Arabia between 2014 and 2015. Arch. Virol. 2018, 163, 1219-1230. [CrossRef] [PubMed]

19. Takashita, E.; Meijer, A.; Lackenby, A.; Gubareva, L.; Rebelo-de-Andrade, H.; Besselaar, T.; Fry, A.; Gregory, V.; Leang, S.-K.; Huang, W.; et al. Global update on the susceptibility of human influenza viruses to neuraminidase inhibitors, 2013-2014. Antivir. Res. 2015, 117, 27-38. [CrossRef] [PubMed]

20. Lee, N.; Hurt, A.C. Neuraminidase inhibitor resistance in influenza: A clinical perspective. Curr. Opin. Infect. Dis. 2018, 31, 520-526. [CrossRef] [PubMed]

21. Goldhill, D.H.; Te Velthuis, A.J.W.; Fletcher, R.A.; Langat, P.; Zambon, M.; Lackenby, A.; S Barclay, W.S. The mechanism of resistance to favipiravir in influenza. Proc. Natl. Acad. Sci. USA 2018, 115, 11613-11618. [CrossRef]

22. Perelson, A.S.; Rong, L.; Hayden, F.G. Combination antiviral therapy for influenza: Predictions from modeling of human infections. J. Infect. Dis. 2012, 205, 1642-1645. [CrossRef]

23. Nguyen, J.T.; Smee, D.F.; Barnard, D.L.; Julander, J.G.; Gross, M.; de Jong, M.D.; Went, G.T. Efficacy of combined therapy with amantadine, oseltamivir, and ribavirin in vivo against susceptible and amantadine-resistant influenza A viruses. PLoS ONE 2012, 7, e31006. [CrossRef]

24. Schoggins, J.W. Interferon-Stimulated Genes: What Do They All Do? Annu. Rev. Virol. 2019, 6, 567-584. [CrossRef]

25. Summers, J.; Cohen, M.H.; Keegan, P.; Pazdur, R. FDA drug approval summary: Bevacizumab plus interferon for advanced renal cell carcinoma. Oncologist 2010, 15, 104-111. [CrossRef]

26. Murira, A.; Lamarre, A. Type-I Interferon Responses: From Friend to Foe in the Battle against Chronic Viral Infection. Front. Immunol. 2016, 7, 609. [CrossRef] [PubMed]

27. Ye, L.; Schnepf, D.; Staeheli, P. Interferon-lambda orchestrates innate and adaptive mucosal immune responses. Nat. Rev. Immunol. 2019, 19, 614-625. [CrossRef] [PubMed]

28. Andreakos, E.; Salagianni, M.; Galani, I.E.; Koltsida, O. Interferon-lambdas: Front-Line Guardians of Immunity and Homeostasis in the Respiratory. Tract. Front. Immunol. 2017, 8, 1232. [CrossRef] [PubMed]

29. Davidson, S.; McCabe, T.M.; Crotta, S.; Gad, H.H.; Hessel, E.M.; Beinke, S.; Hartmann, R.; Wack, A. IFNlambda is a potent anti-influenza therapeutic without the inflammatory side effects of IFNalpha treatment. EMBO Mol. Med. 2016, 8, 1099-1112. [CrossRef] [PubMed]

30. Hermant, P.; Michiels, T. Interferon-lambda in the context of viral infections: Production, response and therapeutic implications. J. Innate. Immun. 2014, 6, 563-574. [CrossRef]

31. Robinson, B.A.; Nice, T.J. You Can Breathe Easy: IFNlambda Handles Flu without Triggering a Damaging Inflammatory Response. Immunity 2017, 46, 768-770. [CrossRef] 
32. Galani, I.E.; Triantafyllia, V.; Eleminiadou, E.E.; Koltsida, O.; Stavropoulos, A.; Manioudaki, M.; Thanos, D.; Doyle, S.E.; Kotenko, S.V.; Thanopoulou, K.; et al. Interferon-lambda Mediates Non-redundant Front-Line Antiviral Protection against Influenza Virus Infection without Compromising Host Fitness. Immunity 2017, 46, 875-890e876. [CrossRef] [PubMed]

33. Mordstein, M.; Kochs, G.; Dumoutier, L.; Renauld, J.C.; Paludan, S.R.; Klucher, K.; Staeheli, P. Interferon-lambda contributes to innate immunity of mice against influenza A virus but not against hepatotropic viruses. PLoS Pathog. 2008, 4, e1000151. [CrossRef] [PubMed]

34. Ramos, E.L. Preclinical and clinical development of pegylated interferon-lambda 1 in chronic hepatitis C. J. Interferon Cytokine Res. 2010, 30, 591-595. [CrossRef] [PubMed]

35. Lasfar, A.; Zloza, A.; Cohen-Solal, K.A. IFN-lambda therapy: Current status and future perspectives. Drug Discov. Today 2016, 21, 167-171. [CrossRef] [PubMed]

36. Mordstein, M.; Neugebauer, E.; Ditt, V.; Jessen, B.; Rieger, T.; Falcone, V.; Sorgeloos, F.; Ehl, S.; Mayer, D.; Kochs, G.; et al. Lambda interferon renders epithelial cells of the respiratory and gastrointestinal tracts resistant to viral infections. J. Virol. 2010, 84, 5670-5677. [CrossRef] [PubMed]

37. Sommereyns, C.; Paul, S.; Staeheli, P.; Michiels, T. IFN-lambda (IFN-lambda) is expressed in a tissue-dependent fashion and primarily acts on epithelial cells in vivo. PLoS Pathog. 2008, 4, e1000017. [CrossRef]

38. Ilyushina, N.A.; Donnelly, R.P. In vitro anti-influenza A activity of interferon (IFN)-lambda1 combined with IFN-beta or oseltamivir carboxylate. Antivir. Res. 2014, 111, 112-120. [CrossRef]

39. Zhu, Y.; Chidekel, A.; Shaffer, T.H. Cultured human airway epithelial cells (calu-3): A model of human respiratory function, structure, and inflammatory responses. Crit. Care Res. Pract. 2010. [CrossRef]

40. BeruBe, K.; Aufderheide, M.; Breheny, D.; Clothier, R.; Combes, R.; Duffin, R.; Forbes, B.; Gaça, M.; Gray, A.; Hall, I.; et al. In vitro models of inhalation toxicity and disease. The report of a FRAME workshop. Altern. Lab. Anim. 2009, 37, 89-141.

41. Essaidi-Laziosi, M.; Brito, F.; Benaoudia, S.; Royston, L.; Cagno, V.; Fernandes-Rocha, M.; Piuz, I.; Zdobnov, E.; Huang, S.; Constant, S.; et al. Propagation of respiratory viruses in human airway epithelia reveals persistent virus-specific signatures. $J$. Allergy Clin. Immunol. 2018, 141, 2074-2084. [CrossRef]

42. Essaidi-Laziosi, M.; Geiser, J.; Huang, S.; Constant, S.; Kaiser, L.; Tapparel, C. Author Correction: Interferon-Dependent and Respiratory Virus-Specific Interference in Dual Infections of Airway Epithelia. Sci. Rep. 2020, 10, 12523. [CrossRef]

43. Tseligka, E.D.; Sobo, K.; Stoppini, L.; Cagno, V.; Abdul, F.; Piuz, I.; Meylan, P.; Huang, S.; Constant, S.; Tapparel, C. A VP1 mutation acquired during an enterovirus 71 disseminated infection confers heparan sulfate binding ability and modulates ex vivo tropism. PLoS Pathog. 2018, 14, e1007190. [CrossRef]

44. Kocabiyik, O.; Cagno, V.; Silva, P.J.; Zhu, Y.; Sedano, L.; Bhide, Y.; Mettier, J.; Medaglia, C.; Da Costa, B.; Constant, S.; et al. Non-Toxic Virucidal Macromolecules Show High Efficacy Against Influenza Virus Ex Vivo and In Vivo. Adv. Sci. $2021,8,2001012$. [CrossRef]

45. Ong, H.X.; Traini, D.; Young, P.M. Pharmaceutical applications of the Calu-3 lung epithelia cell line. Expert Opin. Drug Deliv. 2013, 10, 1287-1302. [CrossRef] [PubMed]

46. Zeng, H.; Goldsmith, C.; Thawatsupha, P.; Chittaganpitch, M.; Waicharoen, S.; Zaki, S.; Tumpey, T.M.; Katz, J.M. Highly pathogenic avian influenza H5N1 viruses elicit an attenuated type i interferon response in polarized human bronchial epithelial cells. J. Virol. 2007, 81, 12439-12449. [CrossRef]

47. Bottcher-Friebertshauser, E.; Stein, D.A.; Klenk, H.D.; Garten, W. Inhibition of influenza virus infection in human airway cell cultures by an antisense peptide-conjugated morpholino oligomer targeting the hemagglutinin-activating protease TMPRSS2. J. Virol. 2011, 85, 1554-1562. [CrossRef]

48. Ilyushina, N.A.; Lugovtsev, V.Y.; Samsonova, A.P.; Sheikh, F.G.; Bovin, N.V.; Donnelly, R.P. Generation and characterization of interferon-lambda 1-resistant H1N1 influenza A viruses. PLoS ONE 2017, 12, e0181999. [CrossRef] [PubMed]

49. Adams, S.E.; Lugovtsev, V.Y.; Kan, A.; Bovin, N.V.; Donnelly, R.P.; Ilyushina, N.A. Laninamivir-Interferon Lambda 1 Combination Treatment Promotes Resistance by Influenza A Virus More Rapidly than Laninamivir Alone. Antimicrob. Agents Chemother. 2020, 64. [CrossRef]

50. Molla, A.; Kati, W.; Carrick, R.; Steffy, K.; Shi, Y.; Montgomery, D.; Gusick, N.; Stoll, V.S.; Stewart, K.D.; Ng, T.I.; et al. In vitro selection and characterization of influenza A (A/N9) virus variants resistant to a novel neuraminidase inhibitor, A-315675. J. Virol. 2002, 76, 5380-5386. [CrossRef] [PubMed]

51. Domingo, E.; de Avila, A.I.; Gallego, I.; Sheldon, J.; Perales, C. Viral fitness: History and relevance for viral pathogenesis and antiviral interventions. Pathog. Dis. 2019, 77. [CrossRef] [PubMed]

52. Boda, B.; Benaoudia, S.; Huang, S.; Bonfante, R.; Wiszniewski, L.; Tseligka, E.D.; Tapparel, C.; Constant, S. Antiviral drug screening by assessing epithelial functions and innate immune responses in human 3D airway epithelium model. Antivir. Res. 2018, 156, 72-79. [CrossRef] [PubMed]

53. George, I.; Uboldi, C.; Bernard, E.; Sobrido, M.S.; Dine, S.; Hagege, A.; Dominique Vrel, D.; Herlin, N.; Rose, J.; Orsière, T.; et al. Toxicological Assessment of ITER-Like Tungsten Nanoparticles Using an In Vitro 3D Human Airway Epithelium Model. Nanomaterials 2019, 9, 1374. [CrossRef] [PubMed]

54. Brookes, D.W.; Miah, S.; Lackenby, A.; Hartgroves, L.; Barclay, W.S. Pandemic H1N1 2009 influenza virus with the H275Y oseltamivir resistance neuraminidase mutation shows a small compromise in enzyme activity and viral fitness. J. Antimicrob. Chemother. 2011, 66, 466-470. [CrossRef] 
55. Duan, S.; Govorkova, E.A.; Bahl, J.; Zaraket, H.; Baranovich, T.; Seiler, P.; Prevost, K.; Webster, R.G.; Webby, R.J. Epistatic interactions between neuraminidase mutations facilitated the emergence of the oseltamivir-resistant H1N1 influenza viruses. Nat. Commun. 2014, 5, 5029. [CrossRef]

56. Pinilla, L.T.; Holder, B.P.; Abed, Y.; Boivin, G.; Beauchemin, C.A. The H275Y neuraminidase mutation of the pandemic A/H1N1 influenza virus lengthens the eclipse phase and reduces viral output of infected cells, potentially compromising fitness in ferrets. J. Virol. 2012, 86, 10651-10660. [CrossRef]

57. Espinola, E.E.; Amarilla, A.A.; Martinez, M.; Aquino, V.H.; Russomando, G. Influenza A H1N1pdm 2009 Virus in Paraguay: Nucleotide Point Mutations in Hemagglutinin and Neuraminidase Genes are not Associated with Drug Resistance. Open Virol. J. 2014, 8, 9-13. [CrossRef]

58. Meseko, C.A.; Heidari, A.; Odaibo, G.N.; Olaleye, D.O. Complete genome sequencing of H1N1pdm09 swine influenza isolates from Nigeria reveals likely reverse zoonotic transmission at the human-animal interface in intensive piggery. Infect. Ecol. Epidemiol. 2019, 9, 1696632. [CrossRef] [PubMed]

59. Pekosz, A.; Newby, C.; Bose, P.S.; Lutz, A. Sialic acid recognition is a key determinant of influenza A virus tropism in murine trachea epithelial cell cultures. Virology 2009, 386, 61-67. [CrossRef]

60. Burke, D.F.; Smith, D.J. A recommended numbering scheme for influenza A HA subtypes. PLoS ONE 2014, 9, e112302. [CrossRef] [PubMed]

61. Colman, P.M. Influenza virus neuraminidase: Structure, antibodies, and inhibitors. Protein Sci. 1994, 3, 1687-1696. [CrossRef]

62. Ferguson, N.M.; Cummings, D.A.; Fraser, C.; Cajka, J.C.; Cooley, P.C.; Burke, D.S. Strategies for mitigating an influenza pandemic. Nature 2006, 442, 448-452. [CrossRef] [PubMed]

63. Lipsitch, M.; Cohen, T.; Murray, M.; Levin, B.R. Antiviral resistance and the control of pandemic influenza. PLoS Med. 2007, 4, e15. [CrossRef]

64. Rameix-Welti, M.A.; Munier, S.; Le Gal, S.; Cuvelier, F.; Agou, F.; Enouf, V.; Naffakh, N.; van der Werf, S. Neuraminidase of 2007-2008 influenza A(H1N1) viruses shows increased affinity for sialic acids due to the D344N substitution. Antivir. Ther. 2011, 16, 597-603. [CrossRef] [PubMed]

65. Pokorna, J.; Pachl, P.; Karlukova, E.; Hejdanek, J.; Rezacova, P.; Machara, A.; Hudlický, J.; Konvalinka, J.; Kožíšek, M. Kinetic, Thermodynamic, and Structural Analysis of Drug Resistance Mutations in Neuraminidase from the 2009 Pandemic Influenza Virus. Viruses 2018, 10, 339. [CrossRef]

66. Paradis, E.G.; Pinilla, L.T.; Holder, B.P.; Abed, Y.; Boivin, G.; Beauchemin, C.A. Impact of the H275Y and I223V Mutations in the Neuraminidase of the 2009 Pandemic Influenza Virus In Vitro and Evaluating Experimental Reproducibility. PLoS ONE 2015, 10, e0126115. [CrossRef] [PubMed]

67. Davidson, S. Treating Influenza Infection, From Now and Into the Future. Front. Immunol. 2018, 9, 1946. [CrossRef] [PubMed]

68. Gubareva, L.V.; Fry, A.M. Baloxavir and Treatment-Emergent Resistance: Public Health Insights and Next Steps. J. Infect. Dis. 2020, 221, 337-339. [CrossRef] 